\title{
KUPAS TUNTAS PENELITIAN PENGEMBANGAN MODEL BORG \& GALL
}

\author{
Sugar Wanto ${ }^{1}$, Ardo Okilanda ${ }^{2}$, Arisman ${ }^{3}$, Muhsana El Cintami Lanos ${ }^{4}$, Dede \\ Dwiansyah Putra ${ }^{5}$, Hikmah Lestari ${ }^{6}$, Mirza Awali ${ }^{7}$, Oktariyana $^{8}$ \\ Universitas PGRI Palembang ${ }^{1,2,3,4,5,6,7}$ \\ Universitas Nahdlatul Ulama ${ }^{8}$ \\ sugar.wanto88@gmail.com ${ }^{1}$
}

\begin{abstract}
Abstrak
Kebugaran merupakan perpaduan dari aktivitas dan olahraga yang dilaksanakan di tempat olahraga, rumah atau tempat lainnya. Senam aerobik merupakan Model ini bersifat kualitatif survey dengan metode lecturing, yaitu menyampaikan ide dan gagasan serta wawasan yang dimiliki masing-masing pemateri kepada para peserta webinar. Teknik pengumpulan data dilakukan dengan wawancara melalui Google Form dan Whatsapp kepada 14 belas mahasiswa Universitas Riau yang melakukan Kuliah Metodologi Penelitian. Hasil menunjukkan bahwa mahasiswa antusias mengikuti pembelajaran daring (dalam jaringan) serta ingin melaksanakan penelitian pengembangan.
\end{abstract}

Kata kunci: Daring, Penelitian Pengembangan, Borg and Gall

\section{FINAL RESEARCH PASSES FOR THE DEVELOPMENT OF BORG \& The COVID-19}

Pandemic has made a very significant change, every university is implementing an online system. An application that is also widely used online is Google Meet. Apart from being unpaid, users can use it for a long time. This service is carried out to students to provide broad insights on Borg and Gall development research, it is hoped that they can actualize their ability to increase productivity in their final thesis on development research. Development research is a type of research that can connect or break the gap between basic research and applied research. This model is a qualitative survey with the lecturing method, namely conveying ideas and insights of each speaker to the webinar participants. The data collection technique was carried out by interviewing via Google Form and Whatsapp to 14 students of the University of Riau who were conducting a Research Methodology Lecture. The results showed that the students were enthusiastic about participating in online learning (online) and wanted to carry out development research. 


\section{WAHANA DEDIKASI}

Key Words: Online, Research and Development, Borg and Gall

Artikel disetujui tanggal:25-04-2020

Corresponden Author: Dede Dwiansyah Putra palembang.ac.id

DOI: http://dx.doi.org/10.31851/dedikasi.v3i1.3023 $^{\text {d }}$

\section{PENDAHULUAN}

Penelitian Pengembangan atau

Research and Development (R \&

D) saat ini merupakan salah jenis penelitian yang banyak dilakukan karena mengingat pentingnya pengembangan ilmu pengetahuan untuk memberikan kemudahan bagi setiap pembelajaran yang dilaksanakan.

\section{Pengertian Penelitian Pengem} bangan atau Research and Developm ent $(R \& D)$ sering diartikan sebagai suatu proses atau langkah-langkah untuk mengembangkan suatu produk baru atau menyempurnakan produk yang telah ada (Sugiyono, 2010). Penelitian pengembangan model dengan media interaktif bisa dilakukan juga secara online (Effendi, \& Hendriyani., 2018). Salah satu jenis penelitian yang dapat menjadi penghubung atau pemutus kesenjangan antara penelitian dasar dengan penelitian terapan yaitu penelitian pengembangan. e-mail:dededwiansyahputra@univpgri-

Produk dalam konteks ini adalah tidak selalu berbentuk hardware (buku, modul, alat bantu pembelajaran di kelas dan laboratorium) (Latief, 2009), tetapi bisa juga perangkat lunak (software) seperti program untuk pengolahan data, pembelajaran di kelas, perpustakaan atau laboratorium, ataupun model- model pendidikan, pembelajaran pelatihan, bimbingan, evaluasi, manajemen dan lainnya. Produk juga berupa pemebelajaran online yang dibuat (Yasa, 2018).

Kegiatan Seminar Online ini merupakan wadah yang sangat tepat untuk masyarakat yang ingin meningkatkan pengetahuan, khususnya dalam bidang penelitian, diperlukan pengarahan oleh pihak yang bertanggung jawab didalam penelitian khususnya di bidang olahraga, sehingga kegiatan ini dapat terlaksana dengan efektif. Oleh karena itu perlu diadakan kegiatan Seminar Online tersebut. 


\section{WAHANA DEDIKASI}

Undang-undang

Tentang

Pendidikan Tinggi (Indonesia, 2012), diartikan bahwa pengabdian kepada masyarakat sebagai kegiatan sivitas akademika untuk mengamalkan dan membudayakan ilmu pengetahuan dan teknologi untuk kemajuan kesejahteraan umum dan dapat mencerdaskan kehidupan bangsa. Program pengabdian kepada masyarakat yang dilaksanakan oleh Perguruan Tinggi (PT) adalah salah satu dari implementasi Tridharma Perguruan Tinggi (Hera, et al., 2018).

Semua program ini dilakukan dalam berbagai bentuk contohnya: pendidikan dan pelatihan masyarakat (Ramadhani, \& Putri., 2019), pelayanan masyarakat, ruang belajar dan kajian dari Ilmu Pengetahuan dan Teknologi (Iptek) yang dilakukan oleh Perguruan Tinggi. Program ini bertujuan menerapkan hasil-hasil Iptek dalam memberdayakan masyarakat sehingga menghasilkan perubahan pengetahuan, keterampilan, dan sikap dari kelompok masyarakat sasaran (Noor, 2010).

Target dan luaran dari Pelatihan ini adalah untuk melaksanakan Tridharma Perguruan Tinggi dan merealisasikan program kerja dari program studi Pendidikan jasmani serta membantu peserta melalui pemahaman tentang penelitian pengembangan. Metode seminar yang digunakan adalah: 1) lecturing, yaitu menyampaikan ide dan gagasan serta wawasan yang dimiliki masing-masing pemateri kepada para peserta webinar, 2) evidence-based learning dimana pesera diajak bersama-sama mendisukusikan materi yang diberikan. Hasil dari seminar ini adalah peserta (para mahasiswa) 1) memahami tentang penelitian pengembangan. 2) memahami modelmodel penelitian pengembangan.

\section{BAHAN DAN METODE}

Kegiatan pengabdian pada masyarakat ini dilaksanakan pada hari Sabtu tanggal 09 Mei 2020 di Universitas Riau. Penelitian dilakukan melalui beberapa tahap yaitu: (1). Membuat ruang google meeet, (2). Menyebarkan pertanyaan secara online melalui sosial media berupa WhatsApp dan google form, (3). Mengumpulkan dan menyaring 


\section{WAHANA DEDIKASI}

data yang sudah diisi oleh mahasiswa untuk kemudian dianalisis sebagai data survey. (4). Teknik analisis data pada penelitian ini, menggunakan teknik analisis kualitatif dengan metode survey dan lecturing.

\begin{tabular}{|l|l|l|}
\hline No & Waktu & \multicolumn{1}{|c|}{ Materi } \\
\hline & & and Gall \\
& & (Muhsana el \\
& & Cintami Lanos, \\
& & Ardo Okilanda, \\
& & Siti Ayu Risma \\
& & Putri) \\
& Penutupan \\
\hline
\end{tabular}

$$
\text { Pada analisis data }
$$
menggunakan survey dan lecturing, diawali dengan proses open member dengan melakukan penyebaran form untuk tingkat pengetahuan terhadap penelitian Borg and Gall. Mahasiswa di Universitas Riau memberikan respon kemudian diproses selanjutnya penyusunan jadwal kegiatan sebagai berikut:

\begin{tabular}{|c|c|c|}
\hline No & Waktu & Materi \\
\hline 1 & $\begin{array}{l}10.30 \quad- \\
11.00\end{array}$ & Persiapan \\
\hline 2 & $\begin{array}{l}11.00 \quad- \\
12.00\end{array}$ & \begin{tabular}{l}
\multicolumn{2}{l}{ Pembukaan } \\
(Ketua Jurusan \\
Program Studi \\
Pendidikan \\
Jasmani \\
Pendiidikan dan \\
Kepelatihan)
\end{tabular} \\
\hline \multirow[t]{4}{*}{3} & \multirow[t]{4}{*}{$\begin{array}{l}12.00 \\
14.00\end{array}$} & $\begin{array}{l}\text { Penjelasan } \\
\text { tentang Jenis } \\
\text { Penelitian } \\
\text { (Dede Dwiansyah } \\
\text { Putra) }\end{array}$ \\
\hline & & $\begin{array}{l}\text { Penelitian } \\
\text { Pengembangan } \\
\text { (Sugar Wanto) }\end{array}$ \\
\hline & & $\begin{array}{l}\text { Model Borg and } \\
\text { Gall (Arisman) }\end{array}$ \\
\hline & & $\begin{array}{l}\text { Contoh-contoh } \\
\text { penelitian Borg }\end{array}$ \\
\hline
\end{tabular}

Acara dimulai pada pukul 11:00 WIB diawali dengan sambutan yang di sampaikan oleh Ketua Jurusan, Ketua Program Studi. Beliau menyampaikan terima kasih kepada pihak Universitas PGRI Palembang krena telah memfasilitasi para Dosen di Universitas PGRI Palembang untuk menyampaikan materi-materi yang disajikan dalam Seminar Online di Universitas Riau tersebut. serta berharap juga bahwa hubungan baik yang selama ini sudah terjalin antara UNRI dengan Universitas PGRI Palembang tidak hanya berjalan sampai disitu, namun berlanjut ke bidang yang lain. Selanjutnya Pukul 12.00 - selesai dilanjutkan penyampaian materi oleh para narasumber (Materi terlampir). Kemudian kegiatan Seminar Online ini ditutup, ucapan terima kasih dari Pihak UNRI dan UPGRI palembang. 


\section{WAHANA DEDIKASI}

\section{HASIL DAN PEMBAHASAN}

Proses Webinar berlangsung dengan baik sesuai jadwal. Semua pihak yang telah berupaya sebaik mungkin sesuai kemampuan dan kondisi yang ada. Kegiatan ini dirasakan sangat perlu, namun diharapkan terdapat peningkatan dalam berbagai aspek sehinga pada kegiatan yang akan datang akan menjadi lebih baik dari pada yang terjadi saat ini.

$$
\text { Hasil akhir dari }
$$

penyelenggaraan kegiatan ini adalah bertambahnya pengetahuan dan pemahaman peserta terhadap penelitian pengembangan dan dapat mengaplikasikan kedepannya sehingga menghasilkan karya ilmiah / skripsi yang membanggakan terhadap Universitas Riau khususnya dalam bidang olahraga. Mahasiswa antusiasn dalam kegiatan seminar online sehingga banyak sekali tanya jawab yang terjadi untuk didiskusikan lebih lanjut. Setelah acara berakhir terlihat respon mahasiswa menghubungi narasumber untuk meneruskan pembimbingan lebih lanjut dengan para narasumber.

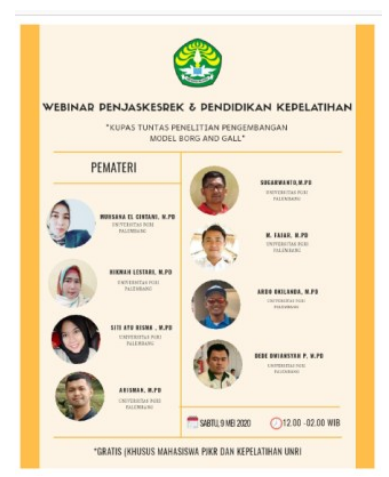

Gambar 1. Poster Kegiatan

Poster ini disebarkan ke masyarakat umum dan mahasiswa Universitas Riau 3 minggu sebelum acara dilaksanakan. Sehingga dapat menarik peserta lebih dari 200 orang.

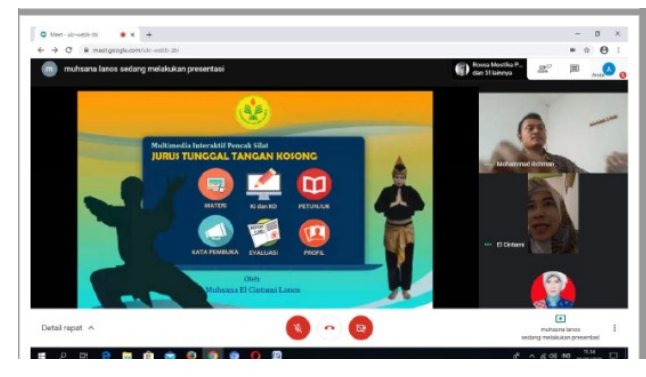

Gambar 2. Penyajian Materi Narasumber Muhasana El Cintami Lanos

Penyajian materi dilakukan pada google meet secara paralel. Sebelum adanya COVID-19 kegiatan perkuliahan berjalan seperti biasa pada setiap perguruan tinggi namun setelah dilakukan social distancing semua mahasiswa tidak lagi bisa melaksanakan kegiatan belajar dikelas seperti biasanya. Pada akhirnya 
semua mengubah kegiatan pembelajaran secara daring (dalam jaringan).

Dari peserta yang 200 peserta yang hadir menghasilkan data survey sebagai berikut:

Tabel 1. Tertarik dan Tidak Terhadap Penelitian Pengembangan

\begin{tabular}{|l|l|}
\hline Mahasiswa & Total Persentase \\
\hline Tertarik & $90 \%$ \\
\hline Tidak Tertarik & $10 \%$ \\
\hline
\end{tabular}

\section{KESIMPULAN}

Setelah diadakannya Webinar ini diharapkan kedepannya para peserta:

1. Akan lebih semangat dalam melakukan penelitian khususnya penelitian pengembangan. Karena setelah mengetahui sebanyak $90 \%$ tertarik pada penelitian pengembangan.

2. Dapat menentukan model yang tepat untuk diikuti kedepannya sesuai dengan tema yang diangkat. Sehingga mahasiswa terbimbing dengan baik untuk menyelesaikan penelitian pengembangan.

\section{Saran}

Seminar Online kali ini hanya terbatas pada pengembangan saja saja. Masih banyak lagi aspek penunjang dalam kajiannya, namun tidak dibahas dikarenakan terkendala berbagai faktor.

Diharapkan kedepannya masih ada lagi kegiatan seminar online yang berhubungan dengan pengembangan potensi penelitian olahraga dalam aspek lainnya, sehingga pendidikan olahraga di Indonesia semakin berkembang.

\section{DAFTAR PUSTAKA}

Effendi, H., \& Hendriyani, Y. (2018). Pengembangan Model Blended Learning Interaktif dengan Prosedur Borg and Gall.

Hera, T., Rochayati, R., Diah, N., Elvandari, E., \& Nurdin, N. (2018). Pelatihan tari lenggang patah sembilan dalam konteks pementasan tari pada siswa-siswi smp negeri $\quad 30 \quad$ kota palembang. Wahana dedikasi, 1(2).

Indonesia, R. (2012). UU RI Nomor 12 Tahun 2012 Tentang Pendidikan Tinggi. 


\section{VAHANA DEDIKASI}

Kemendikbud. (2020). Buku-

Pedoman-PKM-2020.

Latief, M. A. (2009). Penelitian

pengembangan. Karya Dosen

Fakultas Sastra UM.

Ramadhani, E., \& Putri, R. D. (2019).

Pelaksanaan konseling pada

anak jalanan. Wahana

dedikasi, 2(1).

Sugiyono, S. (2010). Metode

penelitian kuantitatif dan

kualitatif dan R\&D.

Yasa, G. A. (2012). Pengembangan

Bahan Ajar Online Mata

Kuliah Micro Teaching

dengan Model Borg \& Gall

pada Program S1 Pendidikan

Bahasa Inggris STKIP Agama

Hindu Singaraja. Jurnal

Ilmiah Pendidikan Dan

Pembelajaran Ganesha,1(1),

207120. 